International Journal of Advanced Biological and Biomedical Research

Available online at http:www.ijabbr.com

Volume 8, Issue 3 (2020) pp. 283-289

DOI: 10.33945/SAMI/IJABBR.2020.3.6

Original Article

\title{
In vitro elaboration Mutagenesis and cloning of the PA gene in Bacillus subtilis
}

\author{
Mohammad Abootaleb*, Narjes Mohammadi Bandari
}

Department of Biology, Qom Branch, Islamic Azad University, Qom, Iran

*Corresponding Author E-mail: mohammad_abootaleb@yahoo.com

Received: 30 September 2019, Revised: 22 January 2020, Accepted: 27 January 2020

\begin{abstract}
Background: The immune antigen of Bacillus anthracis is a protein that can attach to the surface receptor of all human cells. At the surface of cancer cells, there is a receptor that activates the uPA (Urokinase plasminogen) that do not exist in normal human cells.

Objectives: The aim of this study was changing the location of the attachment of the PA gene by a directed mutation in order to attach only to the cancer cells.

Methods: PA gene was extracted from the pMNA1 plasmid. The mutation on the PA gene was made by Overlap Extension PCR. The mutated segment was transferred to DH $5 \alpha$; the strain of Escherichia coli. With TA coning carrier. By restriction enzymes Hind III and BamH I the mutated PA gene was extracted and transferred to pWB980 and by electroporation method, it was transferred to the WB600 strain.

Results: In this study, the mutation occurred in sequences of PA gene by SOE PCR method resulting in a change in the genetic code of amino acid 194. The occurrence of mutation was confirmed by determining base sequences.

Conclusion: Cancer is a severe disease that has a major impact on large groups of people, about whom the problem of cancer is a leading cause of death across the world. One of the treatment methods of cancer is bacterial toxins if only cancer cells receive them. Therefore, these mutated PA proteins can be effective as novel therapeutic agents for the treatment of cancer.
\end{abstract}

Key words: Protective antigen, Overlap Extension PCR, Immune antigen, Urokinase Plasminogen Activator, B. subtilis

\section{Introduction}

Bacillus anthracis the causative agent of anthrax is the Gram-positive, endospore-forming aerobic or facultatively anaerobic and rod-shaped bacterium (Helgason et al., 2011). Anthrax toxins are composed of three proteins components the protective antigen (PA), edema factor (EF), and lethal factor (LF). These proteins are encoded by Pag, Lef, and Cyo genes. LF and EF are associated with PA causing different pathogenic responses (Ivanova et al., 2003). 
The PA protein with a molecular weight of $83 \mathrm{kD}$ and consists of four domains that are connected to cell surface receptors such as $\mathrm{uPA}^{1}$ through their carboxyl-terminal residues. In the following process, after creating a pore in the cell, subunits LF and EF of toxin bind to the PA subunit and transfer into the cell (Cunningham et al., 2002; Liu et al., 2009). uPA is a serine protease present in humans and animals. uPA has an important role in extracellular matrix degradation during cell proliferation. The genes are assembled in syntenic domains on human chromosomes 8, 19, 6 (Casey et al., 1994; Zhang et al., 2011).

The high expression of $\mathrm{UPA}$ and its receptor $\left(\mathrm{uPAR}^{2}\right)$ correlate with various tumors in cells of the body, decomposition inhibitor for extracellular matrix, cell adhesion, motility and invasion (Abi-Habib et al., 2006; Deryugina et al., 2012; Wang et al., 2001). SDM ${ }^{3}$ is an invaluable research tool used in genetic engineering and molecular biology. This method is often performed by $\mathrm{PCR}^{4}$ technique, especially SOE PCR ${ }^{5}$ which is a simple, accomplished technique for SDM and gene splicing. The purpose of this study is to generate Mutations in the PA gene by SOE PCR and cloning it's into the B. subtilis by using the pWB980 expression vector.

\section{Experimental}

\section{Methods}

\section{Bacterial strains and plasmids}

E. coli strain Top10 and B. subtilis strain wB600 were obtained from a gene bank in the Pasteur Institute of Iran, plasmids used in this study, plasmid TA Cloning Vector as a T. vector and expressive plasmid pWB980 as a carrier.

\section{Media}

Strains were maintained in LB medium bottle and LB agar plate (SRL, India) containing ampicillin $100 \mu \mathrm{g} / \mathrm{mL}$ and Kanamycin $10 \mu \mathrm{g} / \mathrm{mL}$ at $37^{\circ} \mathrm{C}$.

\section{Plasmid isolation}

In this study, B. subtilis strain wB600 was used containing pMNA1 plasmid that contained PA for extracting PA Purification of plasmid DNA from B. subtilis by using phenol/chloroform extraction method.

\section{PCR reaction and DNA manipulations}

The primers (F1 and R2) used for the amplification of the PA genes and the primers (F1 and R2) produced the first intermediate segment by $600 \mathrm{bp}$ size and the primers (F2 and R1) produced the second intermediate fragment $1800 \mathrm{bp}$ size. To reproduce intermediate fragments, Ex Taq DNA Polymerase enzyme was used. The final fragment of mutated PA was produced by overlap extension PCR using overlapping supplementary fragments $17 \mathrm{bp}$. Finally, to duplicate mutated PA was used to F2, R2 primers and Ex Taq DNA Polymerase enzyme (Table 1 shows the primer sequences).

1. Urokinase Plasminogen Activator

2. Urokinase Plasminogen Activator Receptor

3. Site-directed mutagenesis

4. Polymerase chain reaction

5. Splicing by overlap extension by pcr 
Table 1. Primers used in reactions

\begin{tabular}{|c|c|c|c|}
\hline Primers & Conditions & Conditions & $\begin{array}{c}\text { PCR volume } \\
(25 \mu \mathrm{l})\end{array}$ \\
\hline $\begin{array}{c}\text { F1: 5'-GTAGGATCCTAAAAGGAGAACGTATATGA-3' } \\
\text { R1: 5'-TAAAGCTTTGTTTAAAACATACTCTCCTTG-3' } \\
\text { F2: 5'-pTGGTGAGTTCGAAGATTTTTGTTTTAATTCTGG-3' } \\
\text { R2:5'- } \\
\text { pGGAAGTGGAAGATCAGCAAGTACAAGTGCTGGACCTACGGTTCCAG- } \\
\text { 3' }^{\prime}\end{array}$ & $\begin{array}{c}1 \text { cycle } \\
25^{\circ} \mathrm{C} \ldots . . .10 \\
\min \\
47^{\circ} \mathrm{C} \ldots . . .60 \\
\min \\
70^{\circ} \mathrm{C} \ldots . . .10 \\
\min \end{array}$ & $\begin{array}{c}1 \text { cycle } \\
95^{\circ} \mathrm{C} . . . .5 \\
\text { min } \\
40 \text { cycle: } \\
95^{\circ} \mathrm{C} . . . .30 \mathrm{~s} \\
58^{\circ} \mathrm{C} . . . .30 \mathrm{~s} \\
72^{\circ} \mathrm{C} . . . .45 \mathrm{~s} \\
1 \text { cycle: } \\
95^{\circ} \mathrm{C} . . . .10 \\
\text { min }\end{array}$ & $\begin{array}{c}\text { 10X PCR } \\
\text { Buffer: } 2.5 \mu \mathrm{l} \\
10 \mathrm{mM} \\
\text { dNTPs: } 0.5 \mu \mathrm{l} \\
10 \mathrm{mM} \mathrm{MgCl} \text { : } \\
0.75 \mu \mathrm{l} \\
10 \text { pmol F+R } \\
\text { Primer: } 1.25 \\
\mu \mathrm{l} \\
\text { Taq DNA } \\
\text { polymerase } \\
(5 \mathrm{u} \mu \mathrm{l}): 0.2 \mu \mathrm{l} \\
\text { Template } \\
\text { DNA: } 1 \mu \mathrm{l} \\
\mathrm{H}_{2} \mathrm{O} \text { up to } 25 \\
\mu \mathrm{l}\end{array}$ \\
\hline
\end{tabular}

\section{Cloning and expression of the PA gene in E. coli and B. subtilis}

The ligation was established between PCR product $500 \mathrm{ng}$ and T. vector $200 \mathrm{ng}$ for providing E. coli containing PA, then the ligation mixture was transformed into E. coli by the standard method ( $\mathrm{CaCl}_{2}$ method). $100 \mu \mathrm{l}$ of transform solutions was transported to LB Agar plate containing ampicillin antibiotic $(100 \mu \mathrm{g} / \mathrm{mL}), X$-gal $(30 \mu \mathrm{g} / \mathrm{mL})$ and IPTG $(2 \mathrm{mM})$. It was then incubated at $37{ }^{\circ} \mathrm{C}$. White colonies were cultured, separated and used for colony PCR and plasmid DNA containing the PA gene was detected by enzymatic digestion after sequencing by Bioscience company. Finally, the mutated PA gene was detected and separated. In the following process, for providing B. subtilis containing mutated PA., the expression vector pWB980 was digested with restriction enzymes Hind III and BamH I followed by DNA being purified by DNA Purification Kit (Viogen, Korea). The ligation was established between plasmid $1 \mu \mathrm{g}$ and fragment of gene $3 \mu \mathrm{g}$. Next, electroporation was performed in $1000 \mathrm{v} / \mathrm{cm}$ and $8.5 \mathrm{msec} .200 \mu \mathrm{l}$ of transform solutions were transported to the LB Agar plate containing Kanamycin antibiotic $(10 \mu \mathrm{g} / \mathrm{mL})$. Then it was incubated for $48 \mathrm{~h}$ at $37^{\circ} \mathrm{C}$.

\section{Statistical analysis}

To analyze the obtained data, SPSS version 23.0 (SPSS, Chicago, IL) was used. T-test and Pearson's chi-square test were employed to interpret the correlation between parameters. The level of significance in the current study was $<0.05$.

\section{Results}

At first, a pMNA1 plasmid containing the PA gene of B. subtilis was isolated. Then, the PCR technique was performed and $2.4 \mathrm{kbp}$ band was observed (Figure 1). Secondly, intermediated fragments were achieved (600 bp and $1800 \mathrm{bp}$ ) by PCR1 and PCR2; these fragments have to overlap with each other (Figure 2). The third, two fragments were used with an equal molar 
concentration in the other PCR reaction (PCR3) and then ligated together. This fusion causes mutated PA gene $2.4 \mathrm{~kb}$ size (Figure 2). T-vector cloning products grew up on the LB agar plate containing ampicillin antibiotic, X-gal and IPTG and the colonies screening by blue-white color, so the presence of PA was verified with colony PCR in (Figure 2).

Finally, the appearance of mutation in PA was approved by sequencing. The mutated PA gene was separated from TA Vector with BamH I and Hind III enzymes (Figure 3). Then it was inserted to pW980 by ligation and solution used for electroporation. The result was verified with single digestion by BamH I and PCR.

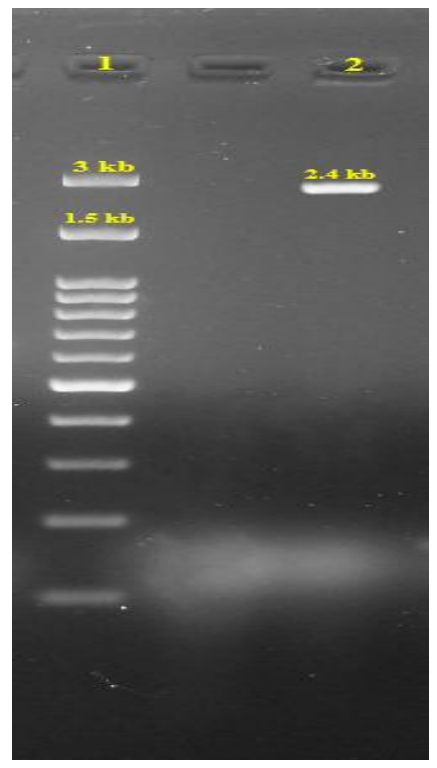

Figure 1. Gel electrophoresis shows the PCR product of PA

Lane 1. Gene ruler 1kb DNA Ladder, Lane 2. PCR product of PA on pW980 plasmid.

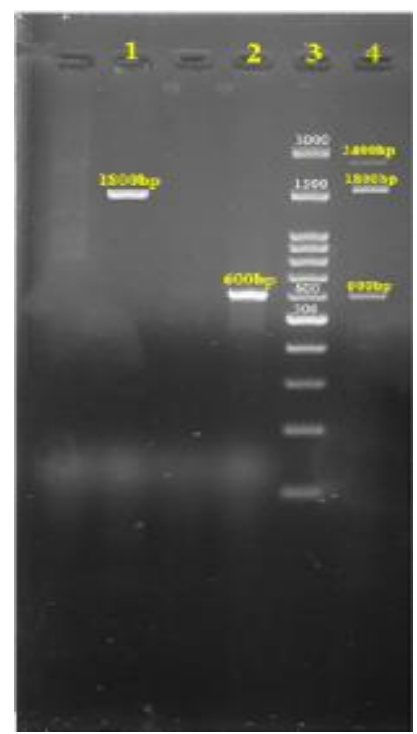

Figure 2. A. Gel electrophoresis shows the pcr1 product

Lane 1. PCR2 product of F1 and R2 primers, Lane 2. PCR1 product of F1 and R1 primers, Lane 3. Gene ruler 100 bp DNA Ladder, Lane 4. Gel electrophoresis shows the PCR3 product 


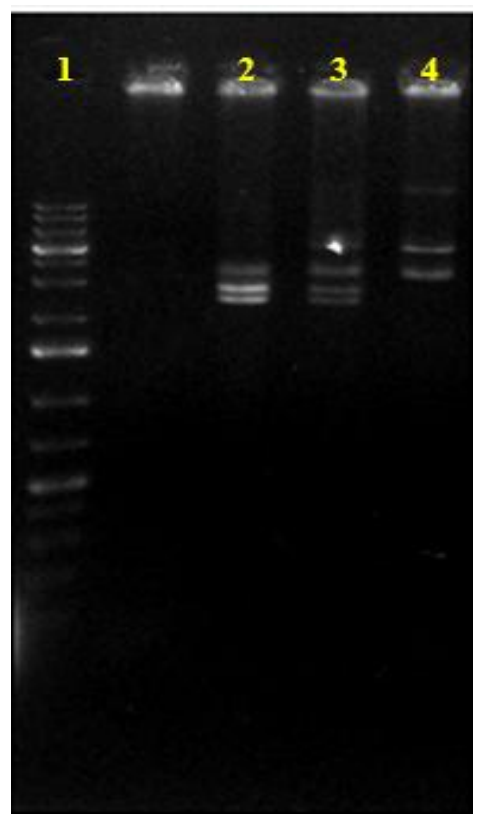

Figure 3. Gel electrophoresis shows the digestion of TA vector with BamH I and Hind III restriction endonuclease

Lane 1. Gene ruler $1 \mathrm{~kb}$ DNA ladder, Lanes 2, 3. digestin enzyme, Lane 4. TA vector plasmid

\section{Discussion}

Anthrax toxin is one of the best-characterized protein delivery systems for tumor targeting. The PA protein can be altered in numerous ways to obtain high specificity for tumors (Wein et al., 2015). Remarkable progress has been achieved in recent years towards the characterization of the structure and function of anthrax toxin that can be manipulated for cancer therapy (Liu et al., 2003).

The current study was performed by designing terminated primers and phosphorylated for a mutation, in the PA gene which is in agreement with the results of (Liu et al., 2003). They developed mutant anthrax toxin and analyzed the anti-tumor effects of the mutated toxin. They used phosphorylated primers and utilized splicing by overlap extension PCR for developing a mutation in the PA gene. In a similar study, (Wein et al., 2015), using an anthrax toxin variant in tumor targeting, have demonstrated the new combination of PA has higher anti-tumor activity and low toxicity in comparison to the performance of the original combination.

In another study, (Rogers et al., 2007) utilized mutant anthrax toxin (protective antigen) for inhibitions angiogenesis and aumor growth. They reported that the anthrax toxin receptor (ATR) ligands, such as PA are angiogenesis inhibitors and that ATRs are useful targets for antiangiogenic therapy.

In our study, the plasmid isolation from B. subtilis was performed using alkaline lysis and some changes, especially in the use of lysozyme, which was easier and less costly than the CsCl-ethidium bromide gradient method. The finding was dissmiliar to that of (Sullivan et al., 2011). They performed plasmid isolation from Bacillus based on CsCl-ethidium bromide gradient and also by boiling method. 
The transformation efficacy of the ligated plasmid DNA into the competent Bacillus subtilis cells is highly dependent on the ratio of plasmid oligomers in the plasmid DNA solution and compared to the shock-induced cells of E. coli at low. In this study, we used electroporation to transfer plasmid DNA, which is a rapid and effective method for the transformation of Bacillus.

\section{Conclusion}

Due to the high prevalence of cancer in the world, it is necessary to have an effective and efficient drug. The result of this study seems to be promising in treating cancer.

\section{Acknowledgements}

The authors wish to sincerely thank Dr. Nazila Arbab Soleimai for her excellent technical assistance and we would also like to thank various people for their contribution, useful and constructive recommendations on this project.

\section{References}

Abi-Habib, RJ, Singh, R, Liu, S, Bugge, TH, Leppla, SH, Frankel, AE. (2006). A urokinaseactivated recombinant anthrax toxin is selectively cytotoxic to many human tumor cell types. Mol. Cancer Ther., 5(10):2556-2562.

Casey, JR, Petranka, JG, Kottra, J, Fleenor, DE, Rosse, WF. (1994). The structure of the urokinase-type plasminogen activator receptor gene. Blood, 84(4):1151-1156.

Cunningham, K, Lacy, DB, Mogridge, J, Collier, RJ. (2002). Mapping the lethal factor and edema factor binding sites on oligomeric anthrax protective antigen. Proc. Natl. Acad. Sci. USA, 99(10):7049-7053.

Deryugina, EI, Quigley, JP. (2012). Cell surface remodeling by plasmin: a new function for an old enzyme. Bio. Med. Res. Int., 2012, Article ID 564259.

Helgason, E, Økstad, OA, Caugant, DA, Johansen, HA, Fouet, A, Mock, M, Kolstø, AB. (2000). Bacillus anthracis, Bacillus cereus, and Bacillus thuringiensis-one species on the basis of genetic evidence. Appl. Environ. Microbiol., 66(6):2627-2630.

Ivanova, N, Sorokin, A, Anderson, I, Galleron, N, Candelon, B, Kapatral, V, Bhattacharyya, A, Reznik, G, Mikhailova, N, Lapidus, A, Chu, L, Mazur, M, Goltsman, E, Larsen, N, D'Souza, M, Walunas, T, Grechkin, Y, Pusch, G, Haselkorn, R, Fonstein, M, Ehrlich, SD, Overbeek, R, Kyrpides, N. (2003). Genome sequence of Bacillus cereus and comparative analysis with Bacillus anthracis. Nature, 423(6935):87-91.

Liu, S, Aaronson, H, Mitola, DJ, Leppla, SH, Bugge, TH. (2003). Potent antitumor activity of a urokinase-activated engineered anthrax toxin. Proc. Natl. Acad. Sci. USA, 100(2):657-662.

Liu, S, Bugge, TH, Frankel, AE, Leppla, SH. (2009). Dissecting the urokinase activation pathway using urokinase-activated anthrax toxin. Methods Mol. Biol., 539:175-190.

Liu, S, Schubert, RL, Bugge, TH, Leppla, SH. (2003). Anthrax toxin: structures, functions and tumour targeting. Exp. Opin Biol. Ther., 3(5):843-853. 
Rogers, MS, Christensen, KA, Birsner, AE, Short, SM, Wigelsworth, DJ, Collier, RJ, D'Amato, RJ. (2007). Mutant anthrax toxin B moiety (protective antigen) inhibits angiogenesis and tumor growth. Cancer Res., 67(20):9980-9985.

Sullivan, MA, Yasbin, RE, Young, FE. (1984). New shuttle vectors for Bacillus subtilis and Escherichia coli which allow rapid detection of inserted fragments. Gene, 29(1-2):21-26.

Wang, Y. (2001). The role and regulation of urokinase-type plasminogen activator receptor gene expression in cancer invasion and metastasis. Med. Res. Rev., 21(2):146-170.

Wein, AN, Peters, DE, Valivullah, Z, Hoover, BJ, Tatineni, A, Ma, Q, Liu, S. (2015). An anthrax toxin variant with an improved activity in tumor targeting. Sci. Rep., 5:16267.

Zhang, J, Sud, S, Mizutani, K, Gyetko, MR, Pienta, KJ. (2011). Activation of urokinase plasminogen activator and its receptor axis is essential for macrophage infiltration in a prostate cancer mouse model. Neoplasia (New York, NY), 13(1):23.

How to cite this article: Mohammad Abootaleb, Narjes Mohammadi Bandari, Mutagenesis and Cloning of the Bacillus Anthracis Protective Antigen Gene in Bacillus Subtilis. International Journal of Advanced Biological and Biomedical Research, 2020, 8(3), 283-289. Link: http://www.ijabbr.com/article 38058.html 